\title{
Cytochemical and ultrastructural observations of anthers and pollen grains in Lathyrus undulatus Boiss.
}

\author{
FILIZ VARDAR*, MERAL ÜNAL \\ Marmara University, Science and Art Faculty, Department of Biology, Göztepe, 34722, \\ İstanbul, Turkey.
}

In Lathyrus undulatus Boiss. (Fabaceae), the young microspore stage of anther development was characterized by the enlarged secretory tapetal cells, which presented an intense reaction with regard to protein, insoluble polysaccharides and lipids. At bicellular pollen stage, the middle layer and the tapetum degenerated. After degradation of the tapetum, epidermis and single row U-shaped endothecium existed in the mature anther wall, and pollen grains remained in the locus. Young microspores had a spherical and centrally located nucleus with one or two nucleoli, many spherical lipid bodies and starchy plastids. A mature pollen grain contains insoluble polysaccharides, proteins, lipids and calcium. The mature pollen had the following morphological characteristics: 3-zonocolporate, prolate, tectate (imperforate) type of exine and perforate type of structure. The intine formed an important constituent portion of the wall, and consisted two sublayers: an outer intine (exintine) and an inner intine (endintine). The well-defined exine was made up of lipoidal substances and protein, but the intine composed of insoluble polysaccharides and protein. The bicellular state of the pollen grains persisted to anthesis.

Keywords: Anther, cytochemistry, Fabaceae, Lathyrus undulatus, microsporogenesis, pollen, SEM, TEM, tapetum.

Abbreviations: PMC - pollen mother cell, PAS - periodic acid-Schiff

\section{Introduction}

Microsporogenesis and pollen grain development have been a focus of interest since generative reproduction in plants depends on pollen structure and function. Disturbances decrease the chance of effective pollination and fertilization of maternal plants (BOHDANOWICZ et al. 2005). Male sterility is mostly due to defects in the development of the microspore or the surrounding nutritive layer, the tapetum. During microsporogenesis, the tapetum performs a secretory role, providing essential nutrients to the developing sporogenous tissue, and later degenerates to facilitate the release of the mature pollen (PACINI 2000). The mature pollen grain is a nutrient storage site necessary for the germination and growth of the pollen tube (RoDriguEZ-GARCIA et al. 2003).

\footnotetext{
* Corresponding author: e-mail: filiz.vardar@gmail.com

Copyright $^{\circledR} 2011$ by Acta Botanica Croatica, the Faculty of Science, University of Zagreb. All rights reserved.
} 
For structural and molecular analysis of anther tapetum, many authors divide the tapetum life span into stages correlated with microspore/pollen grain development (PLATT et al. 1998, Koltunow et al. 1990).

This paper reports observations on the development and cytochemistry of anthers in Lathyrus undulatus Boiss. (Fabaceae), which belongs to the Papilionoideae subfamily, endemic to northwestern Turkey. The genus Lathyrus L. (Fabaceae) comprises approximately 200 species, represented by 77 Lathyrus taxa, 23 of which are endemic to Turkey (DAVIS 1970, 1988; GÜNEŞ and ÇIRPICI 2008).

Pollen morphological characters have been established to elucidate the phylogenetic relationship of Lathyrus genus within the Papilionoideae (EVREN et al. 1994, MANTAR et al. 2003, Tosheva and Tonkov 2005). Taxonomy within the genus cannot be solved by morphological analysis (MANTAR et al. 2003). Embryological characters and the study of the male reproductive organ within the Lathyrus genus, mainly relating to meiotic chromosomes of pollen mother cells (LATTER 1925). A few studies described the female gametophyte development in Lathyrus (REMBERT 1969, DAVIES and WILLIAMS 1985), but no attention has been given to the structural and cytological aspects of the male gametophyte.

The present paper provides research on anther and pollen grain development in Lathyrus undulatus, by the application of light, fluorescence and electron microscopy.

\section{Material and methods}

Flower buds of Lathyrus undulatus Boiss. (Fabaceae) growing in natural habitats in the vicinity of Beykoz-İstanbul (Turkey) were collected in March-April. One anther from the each flower bud was gently dissected and squashed in DAPI (concentration $1 \mu \mathrm{g} \mathrm{mL}^{-1}$ ) for estimation of the development stage (SCHWEIZER 1976).

Flower buds were fixed in $3 \%$ glutaraldehyde in $0.05 \mathrm{M}$ cacodylate buffer at $\mathrm{pH} 7.4$ for $6 \mathrm{~h}$ at $4{ }^{\circ} \mathrm{C}$ and post-fixed in $1 \%$ osmium tetroxide in the same buffer for $4 \mathrm{~h}$ at $4{ }^{\circ} \mathrm{C}$. The samples were dehydrated in ethanol series, and embedded in epoxy resin using propylene oxide. Ultrathin sections $(\sim 70 \mathrm{~nm})$ contrasted with uranyl acetate and lead citrate, and examined with a JEOL JEM 1011 transmission electron microscope (TEM).

For cytochemical observations, the osmication step was omitted from the fixation. Semi-thin sections $(1 \mu \mathrm{m})$ were stained with periodic acid-Schiff (PAS) (FEDER and O'BRIEN 1968) for insoluble polysaccharides, Coomassie Brilliant Blue (FISHER 1968) for proteins, Sudan Black B for lipids (PeArse 1961), Alizarin Red S (McGee-Russel 1958) for intracellular $\mathrm{Ca}^{2+}$ and Auramine O (HESLOP-HARRISON and SHIVANNA 1977) for sporopollenin and exine.

\section{Results}

The anther development of Lathyrus undulatus Boiss. was separated into 5 stages: premeiotic stage, tetrad stage, young microspore stage, vacuolated pollen stage and bicellular pollen grain stage.

The undifferentiated anthers of L. undulatus were ovoid and consisted of meristematic cells encircled by an epidermal layer. Concurrent with development, the anther turned out 
to be tetrasporangiate. In each anther lobe 2-4 hypodermal cells differentiated into archesporial cells, going in a parallel plane to the outer wall of the anther (periclinal divisions), cutting off parietal cells toward the epidermis and primary sporogenous cells toward the interior of the anther. The cells of the parietal layer formed concentric layers of wall endothecial, middle and tapetal layer (dicotyledonous type) by a series of periclinal and anticlinal divisions. Meanwhile the sporogenous cells enlarged and underwent mitotic divisions once generating pollen mother cells (PMCs). The enlargement of anthers was in progress during meiotic division of PMCs. Pollen sacs combined by tissue fusion were subsequent to the pollen maturation. Mature pollen grains scattered to the environment concurrent with dehiscence of stomium.

In Lathyrus undulatus an anther locule containing the developing microspores was bordered by four different layers: the tapetum, the middle layer, the endothecium and the epidermis at the early development stages. The secretory tapetal cells with emphatic nuclei and large volume resembled PMCs (Fig. 1a). Cytochemical reactions revealed that anther wall cells presented a weak reaction with regard to protein, insoluble polysaccharides, lipids and intracellular $\mathrm{Ca}^{+2}$ as carried out by Coomassie brilliant blue, PAS, Sudan black B and Alizarin red S, respectively (Figs. 1a, 2a, 3a, 4a). At the tetrad stage, the organic compounds and intracellular $\mathrm{Ca}^{+2}$ started to accumulate in the tapetal cells in comparison to the other anther wall cells. The tapetal cell was polarized, and most of the cytoplasm was located on the locular side. The vacuole of tapetum grew progressively, and took up almost the whole cellular volume (Figs. 1b, 2b, 3b). At young microspore stage, uninucleated tapetal cells enlarged and the cytoplasm became denser. Insoluble polysaccharides, pro-
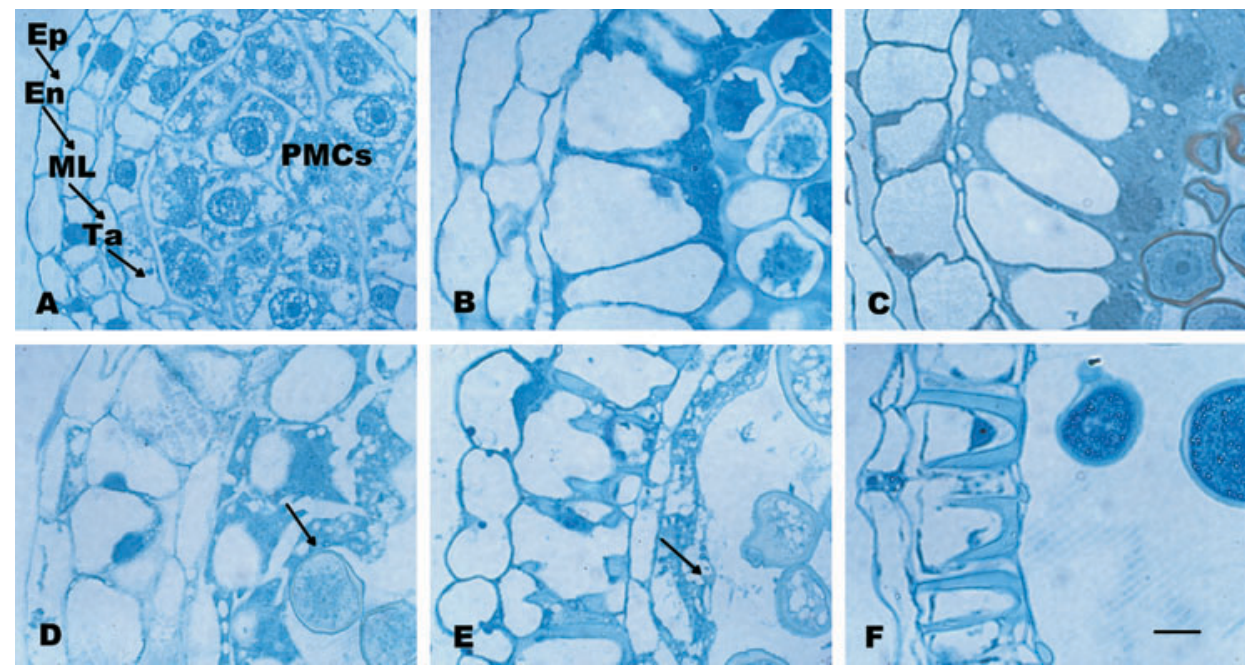

Fig. 1. Semi-thin sections of Lathyrus undulatus anthers at different developmental stages stained with Coomassie brilliant blue. A-PMCs at premeiotic stage and anther wall layers, epidermis (Ep), endothecium (En), middle layer (ML) and tapetum(Ta). B - Enlarged tapetal cells at tetrad stage with large central vacuole. $\mathbf{C}$ - Young microspore stage, tapetal cells with denser cytoplasm. D, E - Vacuolated microspore stage, degenerating tapetum (arrow in E) and pollen-tapetum connection (arrow in D). F - Bicellular pollen stage, disintegrated tapetal cells. Bar denotes $10 \mu \mathrm{m}$ in $\mathrm{A}-\mathrm{F}$. 

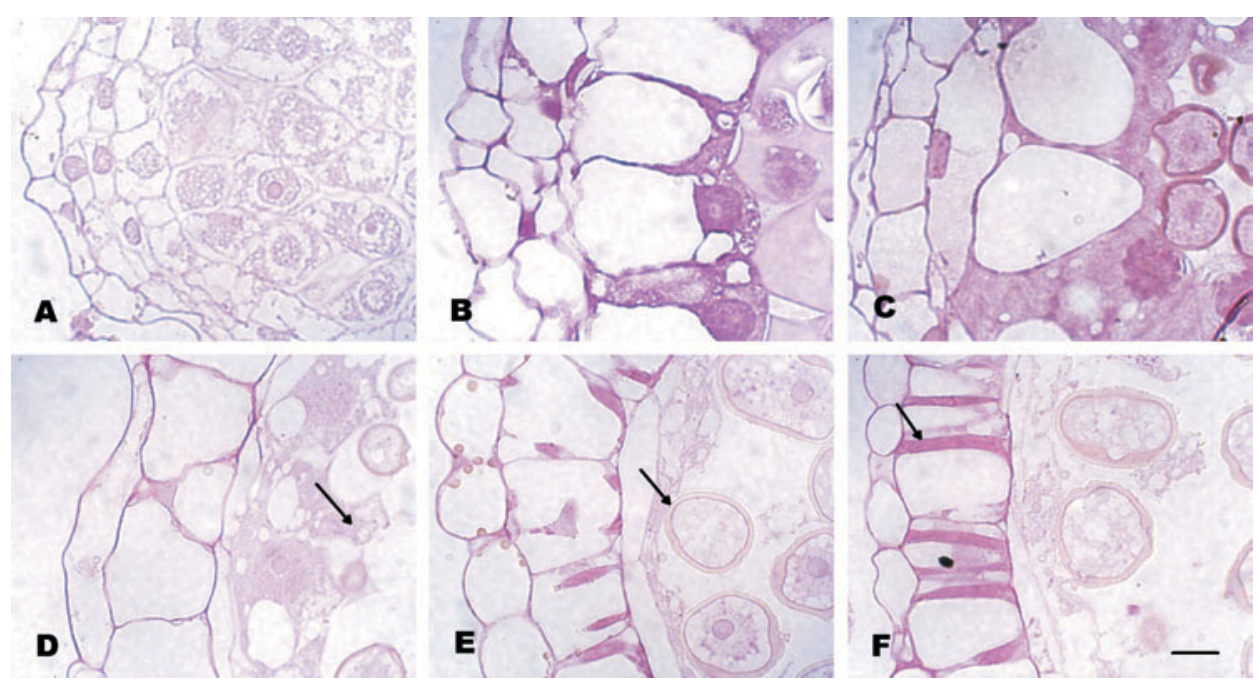

Fig. 2. Semi-thin sections of Lathyrus undulatus anthers at different developmental stages stained with PAS. A - PMCs at premeiotic stage and anther wall cells. B - Enlarged tapetal cells at tetrad stage with large central vacuole. C - Young microspore stage, tapetal cells with denser cytoplasm. D, E - Vacuolated microspore stage, degenerating tapetum and pollen-tapetum connection (arrow). F - Bicellular pollen stage. Arrow denotes PAS positive endothecial thickening. Bar denotes $10 \mu \mathrm{m}$ in A-F.

teins and lipids were indicated in the cytoplasm (Figs. 1c, 2c, 3c). Auramine O dye indicated cytoplasmic lipoidal globules containing sporopollenin precursors which were denser in the locular side of tapetum (Fig. 3d). As well as the organic compounds, intracellular $\mathrm{Ca}^{+2}$ was increased in the tapetal cytoplasm and nucleus (Figs. 4b, c). At vacuolated pollen stage, the tapetum underwent important modifications. During this period, the volume of tapetal cell was reduced, the central vacuole collapsed, and the cytoplasm dispersed in the locule. The degenerating tapetal cytoplasm was abundant in protein, insoluble polysaccharides and calcium (Figs. 1d, e; 2 d, e; 4d) although it was poor in lipoidal substances (Figs. $3 e, f)$.

Microspore mother cells of $L$. undulatus showed a regular meiotic division, and the processes of pollen development progressed normally within each individual anther as well as in all anthers of the same flower. Meiotic division was followed by simultaneous cytokinesis. Callose accumulation started at the corners of PMCs in the early stages of prophase I. Microspore tetrads mostly showed a tetrahedral arrangement, and four microspores were separated from each other by a callose wall (Fig. 5)

As tapetal degeneration progresses, cytochemical tests showed that tapetal remnants consisted of dense protein and polysaccharides were in contact with the pollen grains. The contact between tapetal remnants and pollen exine were visible ultrastructurally (Figs. 6b, c). Endothecial wall thickenings initiated at the mentioned stage and reacted PAS-positive (Figs. 2e, f). At bicellular pollen stage, the middle layer and the tapetum degenerated completely. After degradation of the tapetum, epidermis and single row U-shaped endothecium existed in the mature anther wall, and pollen grains remained in the loculus (Fig. 1f) 

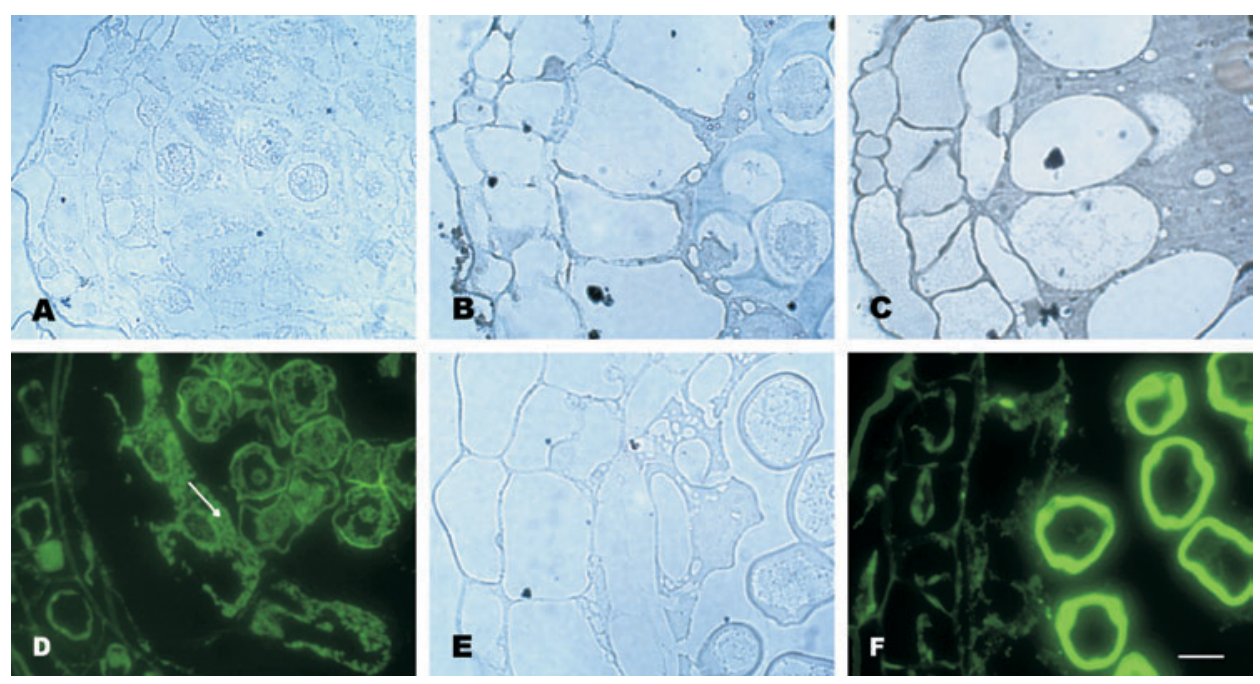

Fig. 3. Semi-thin sections of Lathyrus undulatus anthers at different developmental stages stained with Sudan Black B (A-C, E) and Auramine O (D, F). A - PMCs at premeiotic stage and anther wall cells. B - Tetrad stage. C - Young microspore stage, tapetal cells with denser cytoplasm. D, E - Vacuolated microspore stage, cytoplasmic lipophilic globules containing sporopollenin precursors (arrow). F-Pollen grains with exine. Bar denotes $10 \mu \mathrm{m}$ in A-F.

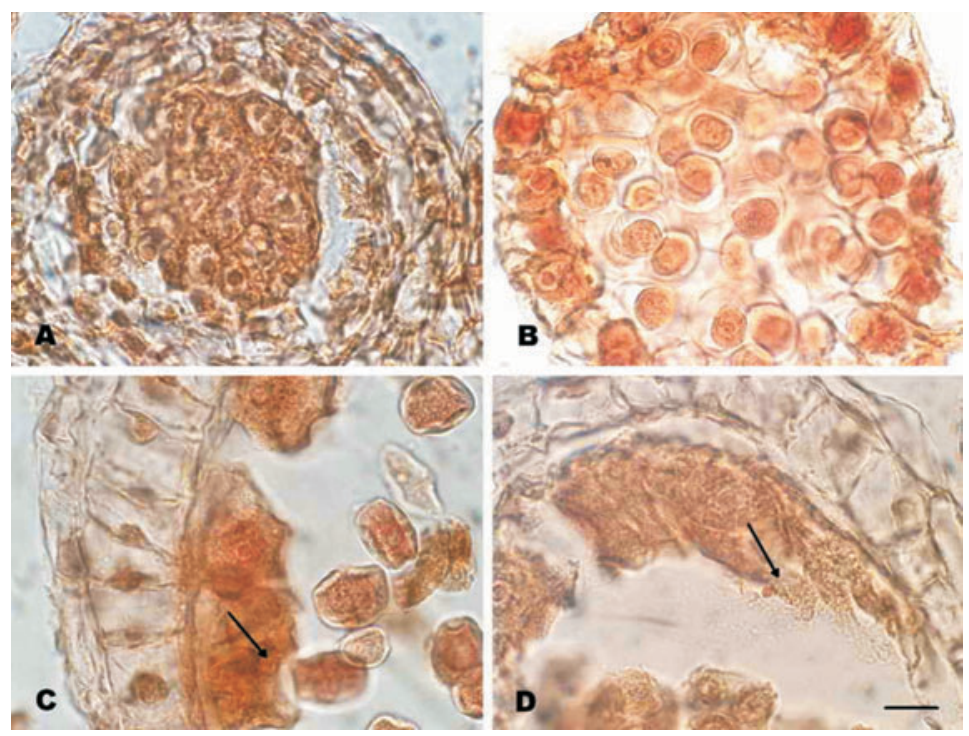

Fig. 4. Lathyrus undulatus anthers at different developmental stages stained with Alizarine red S. A PMCs at premeiotic stage and anther wall cells. B - Tetrad stage. $\mathbf{C}$ - Young microspore stage, tapetal cells with intracellular $\mathrm{Ca}^{2+}$ deposits. D - Vacuolated microspore stage, degenerating tapetum (arrow). Bar denotes $10 \mu \mathrm{m}$ in A-D. 

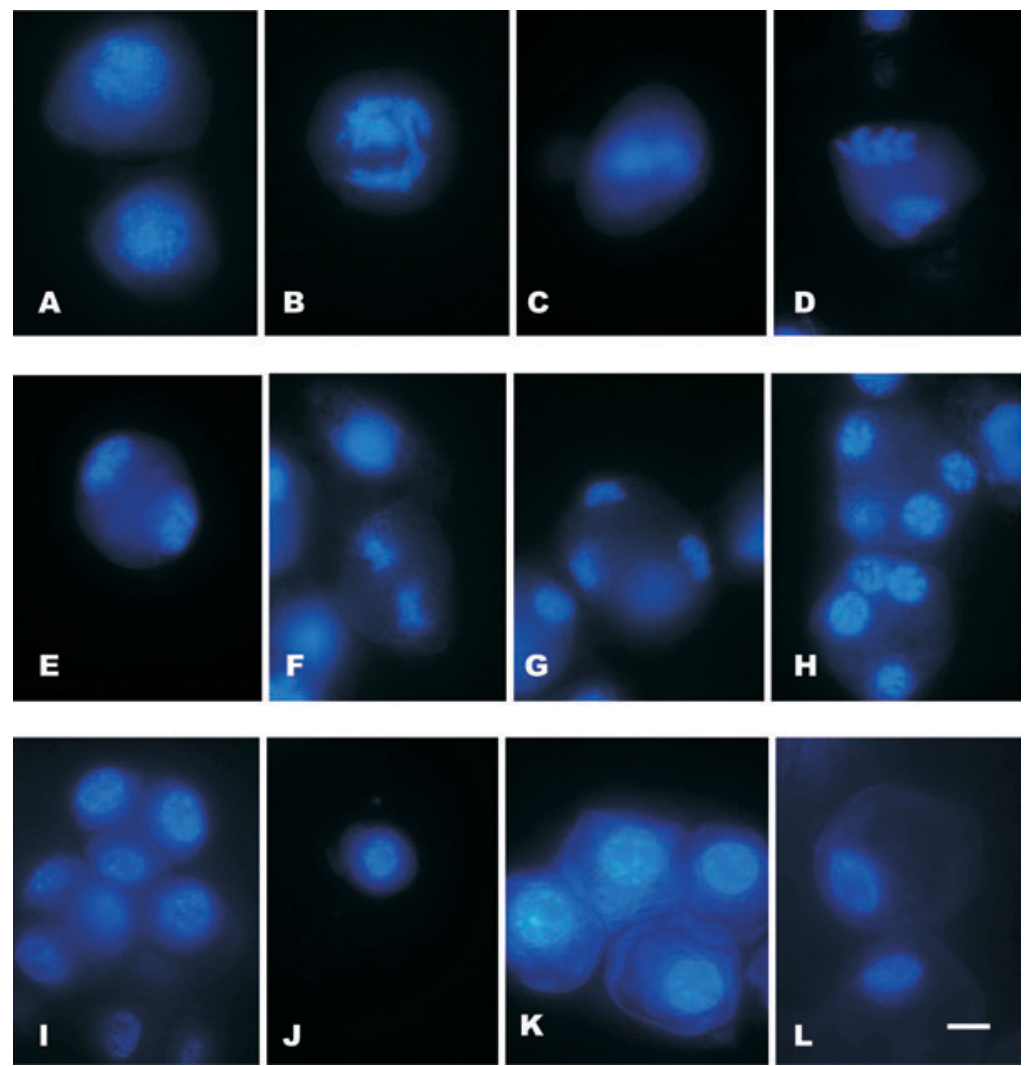

Fig. 5. Microsporogenesis in Lathyrus undulatus anthers. A - PMC, B - Prophase I., C - Metaphase I., D - Anaphase I., E - Telophase I., F - Metaphase II., G - Anaphase II., H - Telophase II., $\mathbf{I}$ - Tetrads., J - Small young microspore, $\mathbf{K}$ - Enlarged young microspores, $\mathbf{L}$ - Mature pollen. Bar denotes $10 \mu \mathrm{m}$.

Ultrastructural observations confirmed that a PMC resembled a meristematic cell with spherical nucleus, dense cytoplasm and thin cell wall at premeiotic stage. At the end of meiosis, the callose wall surrounding tetrads underwent progressive lysis, and the young microspores were liberated into the locule cavity. The free microspores which had spherical and centrally located nucleus with one or two nucleoli started to round up (Fig. 6a). Many spherical lipid bodies and starchy plastids were distributed throughout the cytoplasm of the young microspore. Then the vacuole expanded concomitantly with the increase in microspore volume, and the nucleus displaced to a peripheral position in the thin layer of cytoplasm (Figs. 6b, c). Division of the pollen took place in the vacuolated stage, and resulted in a large vegetative and generative cell (Fig. 6d). At shedding time the pollen grains were 2-celled with a generative cell and a vegetative cell. The vegetative nucleus was spherical and usually had one nucleolus. The elliptical generative nucleus became elongated in further. The generative cell was bounded by a plasma membrane (Fig. 6e).

The mature pollen had the following morphological characteristics: 3-zonocolporate, prolate, tectate (imperforate) type of exine and perforate type of structure. The pollen wall 

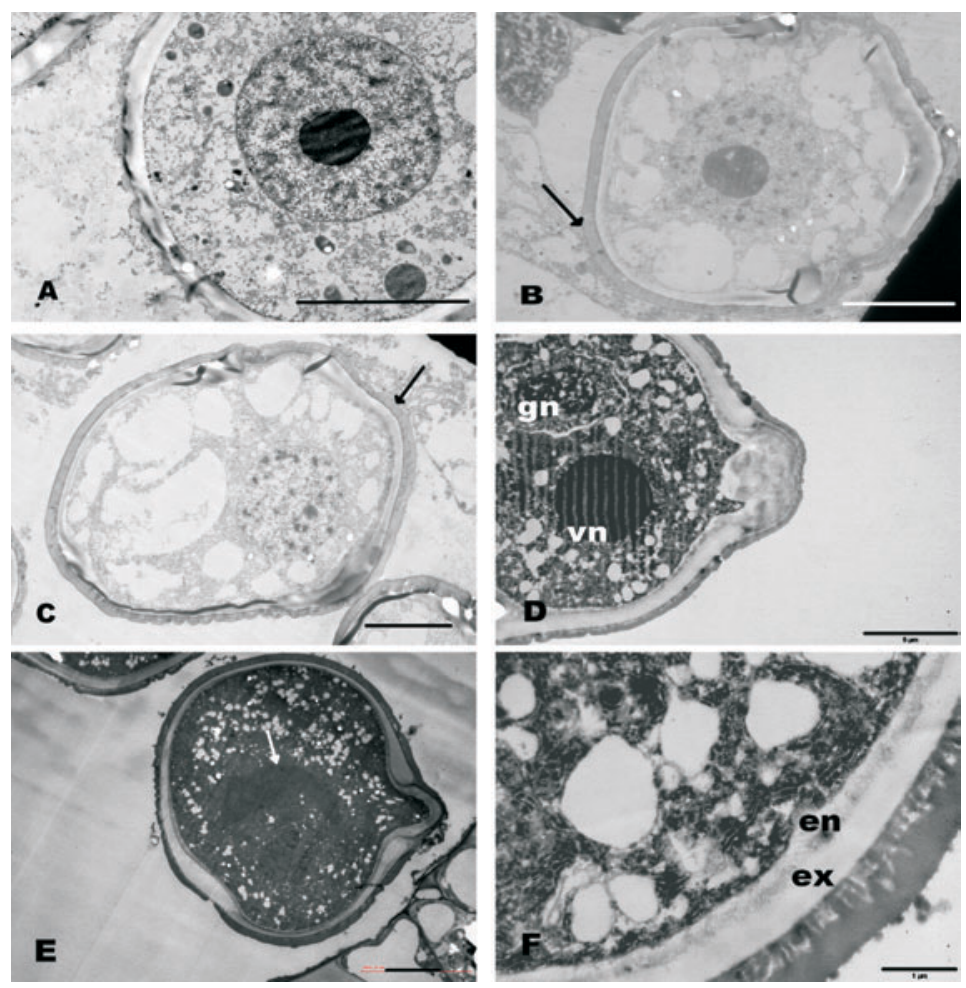

Fig. 6. Ultrastructure of pollen grains, from young microspore to bicellular polen stage. $\mathbf{A}$ - Young microspore with central nucleus. $\mathbf{B}, \mathbf{C}-$ Vacuolization in microspore, degenerating tapetum and pollen connection (arrows). D - Mature pollen grain with vegetative (vn) and generative nucleus (gn). $\mathbf{E}$ - Mature pollen grain with elongated generative nucleus (arrow). $\mathbf{F}$ - Exine and two sublayers of intine; exintine (ex) and endintine (en). Bar denotes $5 \mu \mathrm{m}$ (A-E) and $1 \mu \mathrm{m}(\mathrm{F})$.

composed of exine and intine. The exine was thin in respect to the intine, initially. Ultrastructural studies revealed that tectate was thick and composed of a darkly stained globular material. Therefore the nexine was considerably thinner than the sexine. The intine formed an important constituent portion of the wall and consisted of two sublayers: an outer intine (exintine), presenting a thick zone, and an inner intine (endintine), which consisted of a reticular network. The endintine was thickened at the germ pore region.

The pollen grain surface and anther dehishence is shown by scanning electron micrographs (Figs. 7a, b). The bicellular state of the pollen grains of L. undulatus persisted to anthesis (Figs. 6f, 7b).

Cytochemical experiments indicated that the cytoplasm of a mature pollen grain was filled with insoluble polysaccharides, proteins, lipids and calcium. It was detected that a well-defined exine was made up of lipid-like substances and proteins, but intine was composed of insoluble polysaccharides and proteins (Fig. 8). 

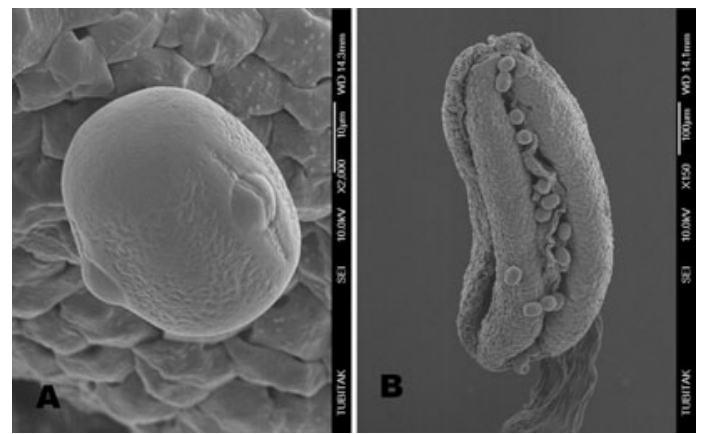

Fig. 7. SEM micrograph of mature pollen (A), and (H) anther dehiscence (B) in Lathyrus undulatus.
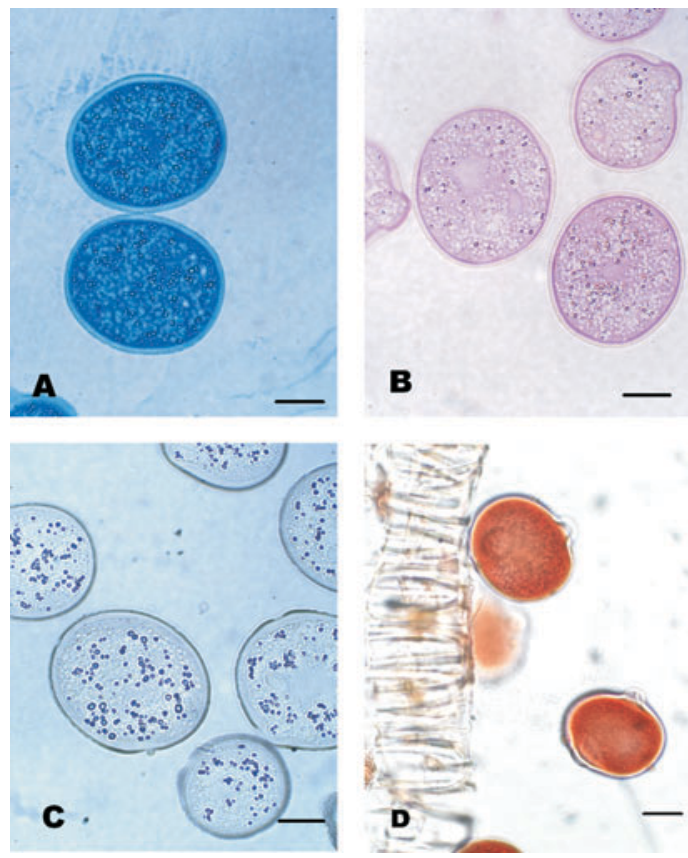

Fig. 8. Cytochemistry of Lathyrus undulatus pollen grains. A - Protein depositions stained with Coomassie brilliant blue. B - Insoluble polysaccharide depositions stained with PAS. C Lipid depositions stained with Sudan Black B. D - Intracellular calcium depositions stained with Alizarin red S. Bar denotes $10 \mu \mathrm{m}$.

\section{Discussion}

Beside chromosome number (GÜNEŞ and ÇIRPICI 2008) and pollen morphology (GÜNEŞ and AYTUĞ 2010), the male gametophyte development was not investigated in Lathyrus.

The anther wall development in Papilionoideae was reported as Dicotyledonous type (Davis 1966), including Trifolium (Hindmarsh 1964), Pisum and Lens (BIDDle 1979, Indigofera (AshrafunNiSA and PULlaiAh 1995), Lotus glaber (GAlati et al. 2006). The 
presented results confirmed that anther walls of $L$. undulatus also belonged to Dicotyledonous type.

The undifferentiated anther of Dumasia miaoliensis (Papilionoideae) was ovoid-shaped and tetrasporangiated (LIU and HUANG 2003), as the observations were showed the similar evidences in Lathyrus undulatus. Furthermore periclinal divisions of sporogenous cells resulted in the formation of pollen mother cells in D. miaoliensis. The researchers stated that at early developmental stages the epidermal, endothecial and middle layer cells had prominent nuclei, large vacuoles, numerous rough endoplasmic reticula and mitochondria. Besides, the microspore mother cells structurally resembled to the tapetal cells.

Analysis of Glycine max has shown that the endothecial thickenings started to accumulate in inner tangential and radial wall at vacuolated pollen stage (ALBERTSEN and PALMER 1979), the same in Lotus glaber (GALATI et al. 2006). The middle layer degenerated at young microspore stage. They found similar timing of developmental alterations as we found in Lathyrus undulatus.

The uninucleate tapetal cells were commonly observed in members of Mimosoideae and Papilionoideae (Buss and LERSTEn 1975, AlBERTSEN and PALMER 1979). The cells of secretory tapetum maintain their position, and eventually undergo degeneration in situ towards the end of pollen development (PACINI et al. 1985). Although, in recent years, it has been known that tapetal cells undergo programmed cell death during degeneration (PAPINI et al. 1999, Wu and CHEUNG 2000), the time of the degeneration varies greatly from species to species. In L. undulatus, the uninucleated tapetal cells developed at young microspore stage, underwent degeneration at vacuolated pollen stage and degenerated completely at bicellular pollen stage.

The tapetum has been considered to be the nutritive tissue for the developing pollen. In the secretory tapetum metabolites in the form of soluble carbohydrates, amino acids and peptides are released into the loculus from which they are taken up by the developing pollen (PACINI 1994). The proteins are located in exine cavities (tectate grain) as pollenkitt/tryphine. It has been reported that (SHIVANNA 2003) orbicules originate in the cytoplasm of the tapetal cells as lipoidal pro-orbicular bodies that accumulate below the membrane and eventually extrude to the cell surface (facing the locule) where they provide sporopollenin precursors for exine formation.

According to our results, the tapetal cells of L. undulatus accumulate protein, carbohydrate and lipoidal substances during development, and after breakdown these derivatives contribute to pollen coat formation. The results confirmed that tapetal derivatives were in contact with pollen grains, and had a possible role in pollen maturation. Several researchers reported that polysaccharides, proteins and lipids existing in pollen cytoplasm had important metabolic roles in pollen germination and pollen tube formation (BEDINGER 1992, Hess 1993, Li et al. 1995).

Calcium plays an important role in plant growth and development. It is implicated in the movement of cellular organelles such as the spindle apparatus and secretory vesicles, and may play a key role in integrating plant cell metabolism (MANIVANNAN et al. 2007). It has been shown that $\mathrm{Ca}^{2+}$ is one of the key elements of apoptotic pathway and alteration of the intracellular $\mathrm{Ca}^{2+}$ concentration can lead to cell death (OLOFSSON et al. 2008). Intracellular $\mathrm{Ca}^{2+}$ increase in tapetal cells of $L$. undulatus as evidenced by the Alizarin red $\mathrm{S}$ may be related to cell death. 
Cytochemical results of Lathyrus undulatus anthers showed that the cells of epidermis, endothecium and middle lamella gave weak reaction for protein, polysaccharides, lipids and intracellular $\mathrm{Ca}^{2+}$. However PAS positive reaction showed that endothecial wall thickenings consisted of polysaccharide. In Chenopodium rubrum (DE FOSSARD 1969) and Triticale (BHANDARI and KHOSLA 1982) endothecial thickenings were described as a kind of polysaccharide, $\alpha$-cellulose.

Lathyrus undulatus underwent simultaneous cytokinesis in the pollen mother cells. Isobilateral microspore tetrads in L. undulatus were shown to be comparable to Vicia galileae (Papilionoideae), as found by DANE and MERiç (1999).

The morphological characters of pollen obtained from TEM and SEM studies were compatible with the other Lathyrus species; however the intine structure was first indicated in the genus Lathyrus.

\section{Acknowledgements}

This work was supported by the Research Foundation of Marmara University (BAPKO no. FEN-DKR 151105-0227).

\section{References}

Albertsen, M. C., Palmer, R. G., 1979: A comparative light and electron microscopic study of microsporogenesis in male sterile and male fertile soy beans (Glycine max L. Merr.). American Journal of Botany 66, 253-265.

Ashrafunnisa, Pullaiah, T., 1995: Embryology of Indigofera (Fabaceae). Taiwania 40, 391-402.

Bedinger, P. A., 1992: The remarkable biology of pollen. Plant Cell 4, 879-887.

Bhandari, N. N., KHOSLA, R. 1982: Development and histochemistry of anther in Triticale cv. Tri-1. I. Some new aspects in early ontogeny. Phytomorphology 32, 18-27.

BIDDLE, J. A., 1979: Anther and pollen development in garden pea and cultivated lentil. Canadian Journal of Botany 57, 1883-1900.

Bohdanowicz, J., SzCZuKa, E., ŚwIERCZyŃSKa, J., SOBIESKa, J., KoŚcińSKA-PAJAK, M., 2005: Distribution of microtubules during regular and disturbed microsporogenesis and pollen grain development in Gagea lutea (L.) Ker.-Gaw. Acta Biologica Cracoviensia 47, 89-96.

Buss, P. A. JR., Lersten, N. R., 1975: Survey of tapetal nuclear number as a taxonomic character in Leguminosae. Botanical Gazette 136, 388-395.

DANE, F., MERiç, Ç., 1999: Reproduction biology of Vicia L.: II. Cytoembryologic studies on anther wall, microsporogenesis, pollen mitosis and male gametophyte development in Vicia galileae Plitm. \& Zoh (In Turkish). Turkish Journal of Biology 23, 269-281

Davis, O. L., 1966: Systematic embryology of the angiosperms. John Wiley and Sons, New York.

Davis, P. H., 1970: Lathyrus L. In: DAVIS P. H., Flora of Turkey, 3, 328-369. Edinburg University Press, Edinburg.

Davis, P. H., 1988: Flora of Turkey. Edinburg University Press, Edinburg.

Davies, S., Williams, W., 1985: The Rate of morphogenesis of embryos and seeds in four species of grain legumes. Annals of Botany 56, 429-435. 
Evren, H., ŞAhin, A., ÇOBANoĞLu, D., 1994: Morphological and cytological features of Lathyrus nissolia L. (Fabaceae) (in Turkish). Turkish Journal of Botany 18, 367-374.

FEDER, N., O’Brien, T. P., 1968: Plant Microtechnique: Some principles and new methods. American Journal of Botany 55, 123-142.

FISHER B. B., 1968: Protein staining of ribboned epon sections for light microscopy. Histochemie 16, 92-96.

De Fossard, R. A., 1969: Development and histochemistry of the endothecium in the anthers of in vitro grown Chenopodium rubrum. Botanical Gazette 130, 10-22.

Galati, B. G., Rosenfeldt, S., Tourn, G. M., 2006: Embryological studies in Lotus glaber (Fabaceae). Annales Botanici Fennici 43, 97-106.

GüNEŞ, F., AYTUĞ, B., 2010: Pollen morphology of the genus Lathyrus (Fabaceae) Section Pratensis in Turkey. International Journal of Agriculture and Biology 12, 96-100.

GüNEŞ, F., ÇIRPICI, A., 2008: Karyotype analysis of some Lathyrus L. species (Fabaceae) from the Thrace region (Turkey in-Europe). Caryologia 61, 269-282.

Heslop-Harrison, Y., Shivanna, K. R., 1977: The receptive surface of the angiosperm stigma. Annals of Botany 41, 1233-1258.

HESs, M. W., 1993: Membrane coatings on the generative cell surface of freeze-substituted monocotyledon pollen. Protoplasma 176, 84-88.

Hindmarsh, G. J., 1964: Gametophyte development in Trifolium pratense L. Australian Journal Botany 12, 1-14.

Koltunow, A. M., Truettner, J., Cox, K. H., Wallroth, M., Goldberg, R. B., 1990: Different temporal and spatial gene expression patterns occur during anther development. Plant Cell 2, 1201-1224.

LATTER, J, 1925: A preliminary note on the pollen development of Lathyrus odoratus. Journal of Experimental Biology 2, 199-209.

Li, Y. Q., Southworth, D., Linskens, H. F., Mulcahy, D. L., Cresti, M., 1995: Localization of ubiquitin in anthers and pistils of Nicotiana. Sexual Plant Reproduction 8, 123-128.

Liu, C. C., HuAnG, T. C., 2003: Anther and pollen wall development in Dumasia miaoliensis Liu and Lu (Fabaceae). Taiwania 48, 273-281.

Manivannan, P., Jaleel, C. A., Sankar, B., Somasundaram, R., Mural, P. V., SridhaRAN, R., PANNEERSELVAM, R., 2007: Salt stress mitigation by calcium chloride in Vigna radiata (L.) Wilczek. Acta Biologica Cracoviensia 49, 105-109.

MAnTAR, N., BAĞCI, E., ŞAHIN, A., GÜR, N., 2003: Morphological, palynological and anatomical studies on Lathyrus sativus L. ve L. hirsutus L. (Fabaceae/Leguminosae) (in Turkish). Science and Engineering Journal of Frrat University 5, 303-314.

McGeE-Russell, S. M., 1958: Histochemical methods for calcium. Journal of Histochemistry and Cytochemistry 6, 22.

Olofsson, M. H., Havelka, A. M., Brnjic, S., Shoshan, M. C., Linder, S., 2008: Charting calcium-regulated apoptosis pathways using chemical biology: role of calmodulin kinase II. BMC Chemical Biology 8, 2.

Pacini, E., Franchi, G. G., Hesse, M., 1985: The tapetum: its form, function and possible phylogeny in Embryophyta. Plant Systematics and Evolution 149, 155-185. 
PACINI, E., 1994: Cell biology of anther and pollen development. In: Williams, E. G., Clarke, A. E., KNOX, R. B. (eds.), Genetic control of self-incompatibility and reproductive development in flowering plants, 289-308. Kluwer Academic Publishers, Dordrecht.

PACINI, E., 2000: From anther and pollen ripening to pollen presentation. Plant Systems and Evolution 222, 19-43.

Papini, A., Mosti, S., Brighigna, L., 1999: Programmed cell death events during tapetum development of angiosperms. Protoplasma 207, 213-221

Pearse, A. G. E., 1961: Histochemistry, theoretical and applied. J. A. Churchill Ltd., London.

Platt, K. A., HuAng, A. H. C, Thomson, W. W., 1998: Ultrastructural study of lipid accumulation in tapetal cells of Brassica napus L. cv. westar during microsporogenesis. International Journal of Plant Science 159, 724-737.

Rembert, D. H., Jr., 1969: Comparative megasporogenesis in Papilionaceae. American Journal of Botany 56, 584-591.

Rodriguez-Garcia, M. I., M'Rani-Alaoui, M., Fernández, M. C., 2003: Behavior of storage lipids during development and germination of olive (Olea europaea L.) pollen. Protoplasma 221, 237-244.

SCHWEIZER, D., 1976: Reverse fluorescent chromosome banding with chromomycin and DAPI. Chromosoma 58, 307-324.

ShivannA, K. R., 2003: Pollen biology and biotechnology, 22. Science Publishers Inc., New Hampshire.

Tosheva, A., Tonkov, S., 2005: Pollen morphology of Bulgarian species from the section Orobus (L.) Gren. et Godr. (genus Lathyrus, Fabaceae). Acta Botanica Croatica 64, 275-287

Wu, H. M., Cheung, A. Y., 2000: Programmed cell death in plant reproduction. Development 44, 267-281. 